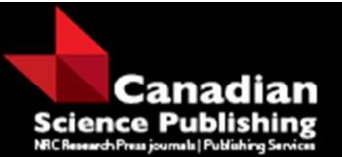

Canadian Journal of Forest Research

Revue canadienne de recherche forestière

\title{
Brown Creeper (Certhia americana) Demographic Response to Hardwood Forests Managed Under the Selection System
}

\begin{tabular}{|r|l|}
\hline Journal: & Canadian Journal of Forest Research \\
\hline Manuscript ID & cjfr-2015-0112.R2 \\
\hline Danuscript Type: & Article \\
\hline Complete List of Authors: & $\begin{array}{l}\text { Geleynse, Daniel; Trent University, Environmental and Life Sciences } \\
\text { Graduate Program } \\
\text { Nol, Erica; Trent University, Biology } \\
\text { Burke, Dawn; Ontario Ministry of Natural Resources } \\
\text { Elliott, Ken; Ontario Ministry of Natural Resources }\end{array}$ \\
\hline Keyword: & $\begin{array}{l}\text { Brown Creeper, selection silviculture, nesting ecology, foraging tree } \\
\text { selection, forestry }\end{array}$ \\
\hline &
\end{tabular}

SCHOLARONE $^{\text {Im }}$

Manuscripts 
1 Brown Creeper (Certhia americana) Demographic Response to Hardwood

2 Forests Managed Under the Selection System

3

4

\section{Daniel M. Geleynse, Erica Nol, Dawn M. Burke, Ken A. Elliott}

5

6 D.M. Geleynse. Environmental and Life Sciences Graduate Program, Environmental

7 Science Centre, 1600 West Bank Drive, Trent University, Peterborough, ON K9J 7B8,

8 Canada. Email: danielgeleynse@trentu.ca.

9 E. Nol ${ }^{1}$. Biology Department, Environmental Science Centre, 1600 West Bank Drive,

10 Trent University, Peterborough, ON K9J 7B8, Canada. Email: enol@trentu.ca.

11 D.M. Burke. Ontario Ministry of Natural Resources, 659 Exeter Road, London, ON

12 N6E 1L3, Canada. Email: dawn.burke@ontario.ca.

13 K.A. Elliott. Ontario Ministry of Natural Resources, 659 Exeter Road, London, ON

14 N6E 1L3, Canada. Email: ken.elliott@ontario.ca.

$15{ }^{1}$ Corresponding author 
16 Abstract: The Brown Creeper (Certhia americana) has been identified as one of the

17 most sensitive passerines to partial forest harvest in North America. The effect of

18 selection logging on Brown Creeper density, nest timing, nest survival, and nest/foraging

19 site selection was examined in 5 silviculture treatments (intensive group-selection, typical

20 group-selection, old single-tree selection, recent single-tree selection and control forests)

21 of Algonquin Provincial Park, Canada. As Brown Creeper nests under the bark of large,

22 decaying trees, we hypothesized that Brown Creeper density, timing of breeding, nest

23 survival, and nest/foraging site selection would be negatively affected by silviculture

24 through the removal of large, decaying trees as part of providing safe conditions for

25 loggers. We monitored 101 nests of Brown Creeper during the 2010 and 2011 breeding

26 seasons, mapped territories to estimate density, and conducted foraging surveys. Brown

27 Creeper density was reduced by about $42 \%$ in logged stands compared to densities in

28 control stands. Despite that, silviculture did not significantly alter timing of breeding or

29 nest survival. Nest trees were significantly closer to small forested wetlands than

30 randomly selected trees in all stands. However, the loss of large trees through partial

31 harvesting meant that Brown Creeper nested closer to adjacent, small forested wetlands,

32 and often in Balsam Fir in treated stands. In control stands, Brown Creeper nested

33 further from forested wetlands, disproportionately in greater numbers in upland

34 hardwoods, and preferentially in the bark of snags of Yellow Birch. The change in the

35 species of tree used for nesting and the general forest type as a result of logging also

36 resulted in consequences for the selection of foraging substrates. To maintain higher

37 densities of Brown Creeper in logged stands in Algonquin Park, we recommend retaining 
38 uncut blocks roughly the size of a Brown Creeper territory (10 ha) containing large

39 diameter Yellow Birch snags.

\section{Introduction}

44 Logging can negatively affect North American breeding bird populations (Vitz 45 and Rodewald 2006). Management concerns for birds that breed in mature forests occur

46 because logging can fragment and reduce the amount of available mature forest breeding

47 habitat, and increase the amount of edge and negative edge effects (Hartley and Hunter

48 1998, Flaspohler et al. 2001, Purcell et al. 2012). Selection or shelterwood silvicultural

49 systems are designed to emulate small-scale natural disturbances that create conditions

50 for regenerating these forests and also minimize impacts on mature forest breeding birds

51 (Lindenmayer et al. 2006).

52 Forest managers have developed guidelines to preserve cavity trees because

53 cavities provide a wide array of habitat to many species (Holloway et al. 2007). In stands

54 managed under the selection system in Ontario, Canada, this recommendation entails

55 retaining 10 living cavity trees $>25 \mathrm{~cm}$ diameter at breast height $(\mathrm{DBH})$ per hectare

56 (Ontario Ministry of Natural Resources 2010). However, for reasons related to worker

57 safety, there are no guidelines in Ontario on the quantity or quality of standing dead trees

58 to be retained in logged stands even though standing dead trees also play an important

59 role in providing forests with essential habitat structures for some species of birds and

60 other wildlife (Angelstam et al. 2003). Effective silviculture should encompass wildlife 
61 habitat needs and plan for a continual supply of standing dead wood to provide long-term

62 structural habitat for many species (Ontario Ministry of Natural Resources 2000, 2004).

63 Standing dead trees are crucial to the Brown Creeper (Certhia americana), whose

64 hammock-like nests are placed in flaking bark (Poulin et al. 2013). Brown Creepers also

65 forage for insects on large live trees with deep bark fissures (Adams and Morrison 1993).

66 Brown Creeper responds negatively to forest edges as nests located farther from edges

67 are more likely to fledge young (Poulin and Villard 2011, Purcell et al. 2012). Thus,

68 Brown Creeper may be affected by increases in the amount of edge habitat and

69 fragmentation created by logging. These relatively strict habitat requirements confine

70 them to areas with mature forest with a high density of standing dead or declining trees

71 for nesting and large trees for foraging (Wiggins 2005).

72 The Brown Creeper was recently identified as one of the most sensitive passerine

73 species to partial logging in North America (Vanderwel et al. 2007). Brown Creeper

74 habitat in North America is limited to protected old growth forests and mature forests

75 where management maintains suitable conditions (Poulin et al. 2013). In Ontario, under

76 the Occupational Health and Safety Act (2010), standing dead trees must be cut or

77 lowered to the ground if in the vicinity of forestry workers felling trees (Ontario Ministry

78 of Labour 2010), although the Stand and Site Guide (OMNR 2010) does suggest leaving

79 these trees when safe to do so. Studies investigating the effect of modern silvicultural

80 practices on forest bird communities show that the Brown Creeper is significantly less

81 abundant in logged areas, attributing this decline mainly to the loss of snags and foraging

82 trees (Mahon et al. 2008, Poulin et al. 2010). Thus, current wildlife habitat

83 recommendations may not be providing adequate habitat for Brown Creepers and 
84 silviculture, in general, may play an important role in determining future Brown Creeper

85 population trends (Wintle et al. 2005).

86 Single-tree selection is the most common silvicultural system used in the tolerant

87 hardwood forests of Algonquin Provincial Park (Algonquin Forestry Authority 2010). On

88 a 20 to 30 year rotational cycle, single-tree selection harvests remove individual trees to

89 release young shade tolerant tree seedlings. The technique often removes trees with

90 declining health and attempts to emulate small-scale natural disturbances such as a

91 single-tree fall gaps or the mortality of small groups of trees (OMNR 2004). The removal

92 of individual trees creates relatively small gaps in the canopy that quickly become filled

93 and create shaded growing conditions, therefore, promoting the growth of shade-tolerant

94 species like sugar maple (Acer saccharum), American beech (Fagus grandifolia), and

95 eastern hemlock (Tsuga canadensis).

96 A benefit of single-tree selection for most forest dwelling birds is the stand

97 remains forested at all times (Medin and Booth 1989) and tree markers can be provided

98 with the direction to maintain certain habitat features. Since European settlement, species

99 like black cherry (Prunus serotina) and yellow birch (Betula alleghaniensis) that require

100 ample sunlight have become less common because of their inability to survive and

101 maintain growth in conditions where the canopies close before the next thinning phase

102 (Quinn 2004). Group-selection silviculture is also based on periodic harvests but removes

103 trees within small gaps (size range 20m-40m across) and may include single-tree

104 selection removals in the areas between the gaps. In Algonquin Park two forms of group-

105 selection silviculture have been employed: intensive, where the matrix is not logged, and

106 typical, where the matrix is also treated with single-tree selection (Falk et al. 2010). The 
107 patches allow more sunlight through the canopy to promote the growth of valuable tree

108 species of mid shade tolerance (Moorman and Guynn 2001). A point count survey

109 indicated Brown Creepers population numbers were not reduced in stands cut through

110 group-selection silviculture in Algonquin Park (Tozer et al. 2010), but that study did not

111 address whether Brown Creepers continued to nest in logged areas after harvest or

112 whether they were displaced to unlogged portions within auditory limits of the surveyed 113 stands.

114 Our goal was to determine whether five forms of silvicultural prescription in

115 Algonquin Provincial Park negatively impacted Brown Creeper nest density and survival,

116 and whether particular nest site characteristics were correlated with higher nest survival.

117 We hypothesized that treatments with less disturbance in the matrix (intensive group

118 selection and old single tree selection), would have higher Brown Creeper densities

119 because they would have more declining or dead trees for nesting than recent single-tree

120 selection or typical group selection where declining trees in the stand are harvested or

121 removed for logger safety. Studies in the same sites on other bird species have not found

122 reductions in nest success in response to silvicultural treatments, suggesting that the

123 predator communities may not be affected by silviculture at the current intensity in the

124 Algonquin landscape (Falk et al. 2011, Leblanc et al. 2011). Therefore we did not predict

125 a change in nest success of Brown Creeper between our logging treatments.

126 We also investigated nest and foraging tree selection by Brown Creeper in stands

127 with different logging prescriptions to determine whether nesting trees with appropriate

128 characteristics (e.g., flaking bark) or foraging trees might be limiting in logged stands,

129 and thus help to explain potential declines in density. We analyzed selection of foraging 
130 and nest tree species and their DBH at the site level and the broader stand level by

131 remotely distinguishing forest types and distances of nests to forested wetlands. We

132 predicted that Brown Creeper in logged treatments would be nesting and foraging on

133 different tree species, and of smaller size than in reference stands. We also predicted that

134 those silvicultural treatments with more intact matrix (intensive group selection) would

135 contain the majority of Brown Creeper nests in the intact matrix areas (i.e., upland

136 hardwoods) compared to treatments with more matrix disturbance where Brown Creeper

137 nests would be closer to unlogged forested refuges. Finally, we examined the effects of

138 silvicultural treatment on Brown Creeper timing of nest initiation, clutch size and length

139 of the nestling period. As Brown Creepers forage on bark, we predicted that, if

140 silviculture reduced foraging substrates, we would see later breeding, lower clutch sizes

141 or longer nestling periods in logged than in control stands.

\section{Methods and Materials}

\section{Study area}

144 The research was conducted in the southern pan handle region of Algonquin

145 Provincial Park (centered on $45^{\circ} 53^{\prime} \mathrm{N}, 78^{\circ} 60^{\prime} \mathrm{W}-45^{\circ} 37^{\prime} \mathrm{N}, 78^{\circ} 21^{\prime} \mathrm{W}$ ), Ontario, Canada.

146 The study area consists of rolling hills and many lakes, rivers and bogs (Martin 1960).

147 The majority of the forest in the study sites was classified in GIS as upland tolerant

148 hardwood forest (75\%) and the remainder as mixed forest with the odd imbedded or

149 adjacent coniferous lowland (2\%). To be classified as mixed forest, the species

150 composition had to contain at least $20 \%$ coniferous species. Tree species consisted

151 largely of sugar maple (68\%), while the remainder was comprised of American beech

$152(9 \%)$, eastern hemlock (9\%), yellow birch (6\%) and black cherry (1\%). The lowland 
153 areas that contained vernal pools (i.e. "forested wetlands" hereafter) were surrounded by

154 balsam fir (Abies balsamea) (1\%) and black spruce (Picea mariana) (1\%). These forested

155 wetlands could be quite small $\left(<100 \mathrm{~m}^{2}\right)$. Within study sites, silviculture prescriptions

156 were restricted to the upland tolerant hardwood forest so that the lowland conifer patches

157 containing forested wetlands had not been logged in many decades (at least $40+$ years).

158 The study sites were part of a continuous forested landscape in Algonquin Provincial

159 Park, which is $7653 \mathrm{~km}^{2}$.

160 Harvest treatments

161 Fifteen study sites or stands, of five treatment types with three replicates ranged in

162 size from $14-72$ ha depending on the prescription area. Reference stands, hereafter

163 "control" sites, had not been logged in at least 60 years and are representative of the

164 region's older growth forests and the natural gap-phase replacement process. Two

165 treatments identified from historical single-tree selection areas were used to provide a

166 space-for-time substitution of impacts of the most common form of silviculture used in

167 tolerant hardwood forests in this area over the past 40 years. Old single-tree selection

168 sites were logged 20-25 years prior to the study (1980-1985) and represent some of the

169 early adaptation to single-tree selection. Recent single-tree selection sites were logged 1-

1705 years prior to the study and represent the current technology and direction from revised

171 recommendations. Recent single-tree selection silviculture in Algonquin includes leaving

172 residual stand basal areas of 17 to $20 \mathrm{~m}^{2} / \mathrm{ha}$, improving stand health, balancing diameter

173 classes and maintaining wildlife habitat including cavity trees. The stands in the two

174 group selection treatments came from an experiment designed to investigate the potential

175 benefits of creating larger gaps for regenerating species of trees that require more 
176 sunlight and may be declining under successive single-tree selection treatments (Falk et

177 al., 2010). The stands were logged using chainsaws and cable skidders. All 6 group-

178 selection stands were previously harvested using single-tree selection sometime between

1791976 and 1984 and current treatments represent the first harvests under the group-

180 selection silvicultural system. Typical and intensive group-selection sites were logged in

181 the winter of 2006-2007, 3-5 years prior to our fieldwork. The typical group-selection

182 prescription was intended to represent the typical application of group-selection

183 silviculture that is currently being used occasionally in Ontario. This method consists of

184 conducting normal single-tree selection across the stand while installing approximately 1

185 to 2 group selection gaps per hectare in ecologically appropriate locations that would

186 provide the best opportunity to establish lesser shade-tolerant species such as yellow

187 birch and black cherry. The circular gap diameters (tree crown to tree crown) were 20-

$18825 \mathrm{~m}$ (approx. $0.03 \mathrm{ha}$ ) for yellow birch and 25-30m (approx. $0.07 \mathrm{ha}$ ) for black cherry.

189 The intensive group-selection prescription, by contrast, restricted all harvesting to

190 the gaps only and used a medium-sized circular gap of $25 \mathrm{~m}$ in diameter ( $0.05 \mathrm{ha})$ gaps in

191 a systematic grid pattern that removed $20 \%$ of the stand's basal area. (see Falk et al. 2010

192 for aerial photo of these treatments). Intensive group-selection increases harvest

193 efficiency while creating patches of early successional forest adjacent to mature unaltered

194 forest. By design, group-selection increases forest structure heterogeneity and creates a

195 variety of habitats that could increase biodiversity (Campbell et al. 2007).

\section{Territory mapping}

197 Brown Creepers were located by sight and sound while walking at a speed of 1-3

$198 \mathrm{~km} / \mathrm{h}$ through the sites. Searching was carried out on rainless days between 5:30am and 
$1992: 00 \mathrm{pm}$. The birds were followed for usually 30-45 minutes to establish the boundaries of

200 their territory. The sex of the bird was recorded, based on the call type. Females often

201 respond instantly to the male's song with a short "zee" call (pers. obs.). We searched each

202 site as a function of Brown Creeper detections. Locations of each bird were marked using

203 a Global Positioning System (GPS) unit. After 6-10 visits to the same sites, and mapping

204 the pair's movements throughout the entire breeding season, territory boundaries could be

205 estimated. Nest locations, counter-singing, and territorial disputes led to more defined

206 boundaries. As first nests were lost to predation and the pair re-nested there was the

207 potential for territory boundaries to shift but they could typically be re-estimated relative

208 to the other territories and in all cases these territories fell at least partially within the

209 boundaries of the old territories.

\section{Nest monitoring}

211 Most nests were found during the nest building stage, in late April or early May in

212 both years of the study $(2010,2011)$. Initially, equal effort was spent searching for Brown

213 Creepers in each of the sites. However, as some sites consistently contained more Brown

214 Creeper activity, we focused on finding all the nests by concentrating our effort in those

215 stands. We are confident, as a result of time spent monitoring the densities of Brown

216 Creepers in the sites, that very few nests were missed on any sites. Brown Creeper nests

217 were also located while mapping territories. Nests located $\leq 4 \mathrm{~m}$ above ground were

218 checked with a fiber optic video camera $(n=65)$, that was equipped with a light on the

219 tip of a rigid $60 \mathrm{~cm}$ arm that transmitted live colour video to a small monitor, to allow

220 recording of nest contents and accurate age of the nest. Nests were revisited every 4-6

221 days throughout laying, incubation and the nestling stage until 2-3 days prior to fledging, 
222 when they were checked every 2-3 days to determine the outcome. Nests $>4 \mathrm{~m}$ above

223 ground were given age approximations (in days) based on parental behavior (e.g.,

224 brooding, size of food, frequency of feedings) and if young were audible $(n=36)$. The

225 nest outcome was considered successful when $\geq 1$ young could be seen out of the nest, or

226 the nest was intact and young were capable of fledging on the previous visit, or when

227 parents were seen carrying food near the nest.

\section{Foraging trees}

229 Brown Creepers were followed while foraging [hereafter "foraging observation"]. After

230 first detected, we waited until the bird flew to a new tree to begin the foraging

231 observation. Once it landed on the new tree, the time spent on each tree, the species of

232 tree, percent moss cover, and DBH of the tree were recorded. If we were unable to follow

233 the bird for $\geq 15$ seconds then the foraging observation was discontinued. Additionally, if

234 the bird was observed preening, perching, or acting defensively, the foraging observation

235 was discontinued. Trees randomly selected $(n=585)$ within the boundaries of each site,

236 were evaluated along a transect that ran through the center of each site, ranging from 500-

2371500 meters, depending on the size of the site. The number of random trees assessed in

238 each site was proportionate to the total number of foraging observations in that site.

239 Random numbers were generated to correspond with the distance from the transect

240 starting point. The closest tree $\geq 10.3 \mathrm{~cm} \mathrm{DBH}$ to the random generated number along the

241 transect was assessed as that size was the smallest DBH foraging tree that we observed a

242 Brown Creeper use. We used the characteristics of these trees to compare to used trees,

243 and assumed that they represented available foraging habitat (Jones 2001). 


\section{Nest vegetation assessment}

$245 \quad$ Nests were revisited after the breeding season to measure vegetation

246 characteristics, so that active nests were not disturbed. The following measurements were

247 taken on each of the trees: DBH, percent bark cover, species, nest height, and health (live

248 or dead). Habitat features within $5 \mathrm{~m}$ of the nest tree were also recorded including the

249 percent cover of regeneration $(0.5 \mathrm{~m}-1.3 \mathrm{~m})$, sapling $(>1.3 \mathrm{~cm},<2.5 \mathrm{~cm} \mathrm{DBH})$,

250 understory layers $(>2.5 \mathrm{~cm},<9.9 \mathrm{~cm} \mathrm{DBH})$, and forest canopy cover. Other

251 measurements, describing the immediate habitat around the nest and placement in the

252 landscape, taken at both nest and randomly selected trees were: basal area, distance to

253 nearest edge (i.e., soft edges: maintained road, lake, large skidder trail, and harvested

254 gaps), distance to canopy gap, and distance to nearest forested wetland. Random nest

255 trees were chosen in the same manner as random foraging trees. The distance from nests

256 and random points to the nearest edge was measured using a GPS unit. We classified a

257 forested wetland as an area that contained standing water or wet soil in spring although it

258 could dry over the course of summer (i.e., vernal pools). A nest was considered to be

259 located in a forested wetland if it was $10 \mathrm{~m}$ or closer to the water's edge. Basal area was

260 measured with a factor-2 prism. Canopy cover was estimated visually at a height of $10 \mathrm{~m}$

261 and $20 \mathrm{~m}$ and the two estimates were averaged for analyses. Tree height was measured

262 with a clinometer or Vertex ${ }^{\mathrm{TM}}$ laser. Nest concealment was measured by estimating the

263 percentage of the nest hidden when viewed from $5 \mathrm{~m}$ away in the cardinal directions and

$2641 \mathrm{~m}$ above and below the nest using a mirror on an extendable pole. These measures were 265 averaged. 
266 To determine the proportion of the upland hardwood and mixed forest in each

267 site, ArcMAP 10 (ESRI 2011) was used. The area of each habitat type (upland hardwood

268 and mixed) was determined by clipping the polygons to each site boundary (Ontario

269 Ministry of Natural Resources 2009, digital forest resource inventory layer, Accessed:

270 2012).

\section{Statistical Analyses}

\section{Nest survival by treatment}

273 Program MARK (White and Burnham 1999) models nest survival with daily

274 survival rates (DSR) varying for each day between nest visits. We tested the hypothesized

275 effect of treatment on nest survival to determine its importance compared to time-

276 dependent variables (e.g., date and year), the latter thought to be important nuisance

277 variables in explaining variation in nest success (Dinsmore et al. 2002, Rotella 2011). .

278 Subsequently, we used a second set of models containing nest tree characteristics,

279 placement of nest in the landscape, and nest characteristics in addition to the top time-

280 treatment model to determine which one was the most important in determining Brown

281 Creeper nest survival. We used the information-theoretic approach to evaluate competing

282 models (Burnham and Anderson 1998) and used model averaging, across all candidate

283 models to incorporate model uncertainty (Buckland et al. 1997, White et al. 2001).

284 Nest survival was generated from program MARK's DSR for each treatment

285 raised to the nest period of 37 days (based on our observation of nests), including 6 days

286 for laying, 15 for incubation and 16 for nestlings. Too few nests were found in any

287 individual silviculture treatment to warrant analysis so nest success was compared

288 between logged and control stands only. 


\section{Site selection}

291 We used the Manly selectivity measure to investigate selection of nesting and

292 foraging tree species. We applied this measure to data from control and logged stands

293 separately (Manly et al. 2002), using package 'adehabitat' in R (R development core

294 team 2011) following the work of Calenge (2006). This method compares the available

295 trees to the trees used for nesting and foraging. The proportion of available tree species

296 was gathered from the random tree transects. For these analyses habitat use and

297 availability were measured at the population level (design I type of analyses) (Manly et

298 al. 2002). We also ran a one-way ANOVA to compare DBH of the nest tree as the

299 dependent variable and tree type (dead coniferous, dead deciduous, live deciduous) as the

300 predictor variables and we ran a t-test to compare DBH in control and logged stands.

301 We used ArcMap 10 (ESRI 2011) to quantify the amount of each forest type (i.e.,

302 upland hardwood and mixed forest) in the sites based on classifications from Ontario

303 Ministry of Natural Resource's Ontario Geospatial Data Exchange forest resource

304 inventory (Ontario Ministry of Natural Resources 2009). We performed a MANOVA to

305 determine if the area occupied by each forest type based on those classifications, was

306 significantly different between the treatments. We performed a chi-square test to

307 determine if Brown Creepers showed a preference for forest types at the stand level using

308 proportions of nests in the two forest types among control and logged treatments. We also

309 compared the differences in the number of nests located in forested wetlands, number of

310 nests in snags vs. live trees, and number of nests in conifer vs deciduous trees using chi- 
311 square tests between control and logged treatments. We also ran a chi-square test to

312 determine the difference in snag availability between control and logged treatments.

313 For foraging trees, we used a general linear model to compare the foraging tree

314 characteristics, DBH, tree height and percent moss cover, with the predictor variables:

315 tree type (random or forage tree), treatment and site nested within treatment, the latter

316 term included to account for the nested structure of the data. We used the 'site nested

317 within treatment' mean square error to calculate the significance of the other main effects

318 to account for the random effect of sites. The three response variables were run

319 separately, all of which were considered, a priori, to be characteristics that helped to

320 define foraging trees of the Brown Creeper (Franzreb 1985).

\section{Densities}

322 We calculated the number of territories and partial territories by territory

323 mapping. If a territory was partially within the site boundary, we estimated the portion of

324 its territory in the site to the nearest $25 \%$. We did not calculate the actual size of the

325 territories because territories in the logged sites straddled the adjacent forested wetland

326 areas and we did not spend as much time determining the outlines of the territory outside

327 our stand boundaries. As a consequence, in logged stands, mostly partial territories of

328 Brown Creeper were present and we totaled up these partial territories to estimate

329 densities. In the unlogged territories the full territory was often contained within the

330 upland hardwood portion of the stand. Density was calculated as the number of pairs per

331 ha. We performed a one-way ANOVA to compare densities between treatments. We also

332 used a one-way ANOVA to compare densities between logged and control treatments. 


\section{Nest parameters}

334 We compared date of first egg, clutch size, length of nestling period, and date of

335 fledging between control and logged areas using t-tests for each year. There were too few

336 nests found in the logged treatments to compare between the different forms of selection

337 silviculture. First nesting attempts were recognizable from second attempts because the

338 first attempt was found after conducting an initial survey of the territory in which pairs

339 had just established and were engaged in courtship activities. These surveys were early in

340 the breeding season, and subsequent visits to the territory were followed with locating the

341 pair during the nest building stage. Second nest attempts were identified when pairs of

342 Brown Creeper were found building a new nest within the same territory as a failed first

343 attempt. We assessed chick age using chicks with known hatching dates as a guide. We

344 used backdating where necessary to provide additional information. The latest date of

345 first egg attributed to a first nest was May $19^{\text {th }}$. We compared nest survival of early

346 (before and including May $\left.19^{\text {th }}\right)\left(75\right.$ nests) and late nests (after May $\left.20^{\text {th }}\right)(13$ nests).

347 We used the statistical programs R version 2.13.1 (R development core team

348 2011), SPSS version 20 (SPSS 2010), and MARK (White and Burnham 1999) for all

349 analyses.

\section{Results}

351 In the two years of the study, 101 active Brown Creeper nests were found and

352 used in subsequent habitat selection analyses. Among those nests, 88 were within the

353 treatment boundaries and had confirmed nest contents of $\geq 1 \operatorname{egg}(2010 n=36,2011 n=52)$

354 and were used in analyses evaluating the effects of silvicultural treatment on nest success.

355 There were $61(69.3 \%)$ first nesting attempts and $27(30.7 \%)$ renests. In both years we 
356 found more than a third of all nests (33/88) in the control stands, despite that control

357 areas comprised only $22 \%$ of the total area where we searched $\left(\chi^{2}=12.3, \mathrm{P}<0.0005\right)$.

358 Apparent nest success (successful nests/all nests) was 63.6\% across all treatments and

359 predation accounted for $87.5 \%$ of all nest failures with nest contents. Four nests with eggs

360 failed due to parental abandonment, and one nest tree fell down.

\section{Densities}

362 There was no significant difference in Brown Creeper densities among the five

363 silvicultural treatments, although all treatments contained lower average densities than

364 control stands $\left(\mathrm{F}_{4,10}=1.8, \mathrm{P}=0.419\right)$ (Fig. 1). When all logged stands were combined into

365 a single logging category, there was a significantly higher density of Brown Creepers

$366\left(\mathrm{~F}_{1,13}=5.0, \mathrm{P}<0.05\right)$, in control than logged stands (control: $0.124 \pm 0.02 \mathrm{pairs} / \mathrm{ha}$,

367 logged: $0.0720 \pm 0.01$ pairs/ ha).

\section{Nest survival by treatment and time}

369 There was little support for the model that included the effect of treatment

370 (control vs. logged) on nest survival and treatment was the least important of the

371 variables included in the models explaining variation in nest survival (Table 1). The

372 variables in the top model and with the greatest weights were date, year, and nest age ${ }^{2}$.

373 Nests initiated earlier had a higher probability of survival. Nest survival of early nests,

374 whose first eggs were laid on or before May $19^{\text {th }}$ (latest date of all first nest attempts) was

$3750.617 \pm 0.0026(n=75)$ whereas nests whose first egg date was after May $19^{\text {th }}$ had a nest

376 survival of $0.433 \pm 0.0091(n=13)$. Nest success was slightly higher in 2011 than 2010 . 


\section{Nest survival by tree characteristics and placement}

378 The models with nest tree characteristics (\% bark cover, tree species, DBH, and

379 dead vs. alive), placement in the landscape (distance to edge, distance to forested

380 wetland, basal area, and canopy cover), and nest characteristics (height and concealment)

381 did not predict Brown Creeper nest survival better than the top model from the treatment-

382 time (Table 1) nest survival model (Table 2).

\section{$383 \quad$ Nest tree selection}

384 In control stands we found 26 nests $(78.8 \%)$ in deciduous tree species and only 7

385 in conifer species while in logged stands $19(34.5 \%)$ were in deciduous tree species and

38636 in conifer species $\left(\chi^{2}=16.2, \mathrm{P}<0.0001\right)($ Table 3$)$. All nests in coniferous trees were

387 located in dead trees, while 10 of the nests in deciduous trees were in living (including

388 declining) trees. The average DBH of coniferous nest trees, dead deciduous and live

389 deciduous nest trees were $35.7 \pm 2.2 \mathrm{~cm}, 49.2 \pm 3.2 \mathrm{~cm}$ and $53 \pm 5.7 \mathrm{~cm}$, respectively

$390\left(\mathrm{~F}_{7,100}=9.31, \mathrm{P}<0.01\right)$. Nest trees in control sites had significantly larger DBH than nest

391 trees in logged sites $(\mathrm{t}=2.2$, d.f. $=86 \mathrm{P}<0.05)$.

392 Patterns of preference varied between control and logged stands. In control

393 stands, Brown Creeper preferred to nest in yellow birch trees while sugar maple trees

394 were under-utilized. In logged stands balsam fir trees were the most frequently selected

395 nest trees while sugar maple was under-utilized (Fig. 2.a).

396 There were no significant differences in the proportions of the remotely assessed

397 forest types (e.g., upland hardwood vs. mixed forest) among treatments (MANOVA, $\mathrm{F}_{8,18}$

$398=0.730, \mathrm{P}=0.665$, Wilk's $\lambda=0.570)$. However, in control sites nests were located

399 significantly more often in upland hardwood forests compared to logged sites $\left(\chi^{2}=6.07\right.$, 
400 d.f. $=2, \mathrm{P}<0.02$, Table 3 ). Snags made up $12 \%$ of randomly selected trees in control

401 sites and only $2 \%$ in logged sites $\left(\chi^{2}=21.3\right.$, d.f. $\left.=2, \mathrm{P}<0.001\right)$ (Table 3$)$. In comparison

402 to site level characteristics Brown Creeper also nested in areas within the stand with

403 higher basal area (Table 3).

\section{Foraging tree selection}

405 We collected 305 foraging observations of Brown Creeper that were on average

$40634.8 \pm 1.2 \mathrm{sec}$ duration. Brown Creeper were recorded foraging on sugar maple trees

$40751.8 \%$ of total foraging time observed. Sugar maple was by far the most dominant tree

408 species and accounted for $68 \%$ of all trees randomly surveyed. Brown Creeper used

409 similar proportions of foraging tree species through the breeding season. From the Manly

410 selectivity measure, no tree species was preferred for foraging in control stands, and most

411 species were used in proportion to their availability on the landscape. In the logged

412 stands, Brown Creeper preferred to forage on: balsam fir, black spruce, yellow birch, and

413 eastern hemlock, all tree species that occupy the forested wetlands. Tree species

414 proportionately under-utilized were sugar maple, which predominately occupy the drier

415 uplands (Fig. 2.b).

416 Trees used for foraging had greater DBH in control stands than in stands of any other

417 treatment (treatment effect: $\mathrm{F}_{4,10}=4.96 . \mathrm{P}=0.006$ ). Forage trees also had significantly

418 greater $\mathrm{DBH}$ than random trees in all treatments (tree type effect: $\mathrm{F}_{1,10}=12.04, \mathrm{P}=$

419 0.0005; no sig. interaction, Table 4). There was no treatment effect for tree height or

420 proportion of moss cover (treatment effect, Height: $\mathrm{F}_{4,10}=0.26$, n.s.; Moss cover: $\mathrm{F}_{4,10}=$

421 0.26, n.s.: Table 4, no significant interactions between treatment and tree type).

422 Randomly selected trees were shorter than forage trees (tree type effect, Height: $\mathrm{F}_{1,10}=$ 
$42322.3, \mathrm{P}<0.001$, Table 4 ) but tree types did not vary significantly in moss cover (moss:

$424 \quad \mathrm{~F}_{1,10}=0.18$, n.s.)

425

\section{Nest parameters}

427 First eggs were laid nearly eight days later in 2011 than in 2010, presumably

428 owing to the later spring in 2011 (mean April temperatures, 2010: $6.9 \pm 0.62{ }^{\circ} \mathrm{C} ; 2011$ :

$4293.25 \pm 0.68^{\circ} \mathrm{C}$ (Environment Canada, Algonquin East Gate weather station), but first egg

430 dates did not vary significantly among control and logged areas in either year. Clutch

431 sizes were largely invariant both between control and logged areas, as were the lengths of

432 the nestling periods, although sample sizes were very small for the latter variable. As

433 expected, the date that young fledged was also later in 2011 , but this date did not vary

434 significantly between control and logged treatments (Table 5).

\section{Discussion}

436 Silviculture in tolerant hardwoods of Algonquin Provincial Park, Ontario resulted

437 in a significant reduction in the number of Brown Creeper territories, as compared to

438 unlogged stands, a reduction that was consistent across all forms of silviculture that we

439 studied. The $42 \%$ reduction in densities of Brown Creeper in logged stands in the park

440 paralleled the significantly fewer nests that were found in those stands. By contrast,

441 Brown Creeper nest survival was not affected by logging, nor were other characteristics

442 associated with Brown Creeper nests including nest initiation dates, clutch size or the

443 length of the nestling periods. We also documented a change in the species of nesting

444 trees selected by Brown Creeper in logged stands, and a reduction in the sizes of nest

445 trees. These changes occurred because in the logged stands significantly more nests were 
446 located in the mixed forest and forested wetland portions of the study sites compared to

447 the unlogged stands. We attribute the reductions in densities that we observed in

448 harvested stands due to the reductions in the availability of Yellow Birch for nesting in

449 the upland portions of the stand. Finally, there were significant changes in the preference

450 of particular tree species used for foraging, albeit with only slight differences in the

451 characteristics of those trees, as a result of logging.

452 Our results of logging impacts on densities of Brown Creepers are very similar to

453 those reported by Poulin et al (2010) who studied this species in hardwood forests under

454 partial harvest in New Brunswick, Canada. In that study, nest density was twice as high

455 in control plots than in treatments. In New Brunswick, Brown Creeper nested in the bark

456 of Balsam Fir even in control stands and there was no significant reduction in Balsam Fir

457 after harvesting. In our study site, Yellow birch is probably preferred as a nesting tree

458 because it can grow very large $(>60 \mathrm{~cm} \mathrm{DBH})$ and has a thick flexible bark that can

459 conceal nests. Once the upland areas were logged, Brown Creeper did preferentially nest

460 in balsam fir snags, as in New Brunswick, despite the much smaller DBH of that species.

461 Like yellow birch, this tree species provides large plates of bark to conceal nests. The

462 availability of yellow birch in the New Brunswick study is unknown although it is

463 considered a dominant species there (Poulin et al. 2010). Why Brown Creeper prefer

464 different species for nesting in the two different regions is not known.

465 Due to the lack of difference in the preferred nesting tree for Brown Creeper in

466 control and harvested stands in New Brunswick, the authors suggested that foraging trees

467 were limited after partial harvest and this reduction caused the decline in densities. In our

468 study, in control stands, Brown Creeper foraged on trees in the upland hardwoods 
469 whereas in harvested stands, they foraged on trees associated with the forested wetlands.

470 Brown Creeper are, like most territorial breeding passerines, central place foragers during

471 the nesting season (Orians and Pearson 1979). This response in the selection of forage

472 trees as a result of relocation of nests to the forested wetlands did not appear to result in a

473 reduction in the ability of Brown Creepers to provision young, as we did not observe any

474 decline in variables associated with food supply that might impact nest performance (e.g.,

475 date of first clutch, clutch size). While Brown Creeper showed strong selectivity for

476 taller and larger trees for foraging, we also documented only moderate treatment effects

477 (on DBH only) on these characteristics. Thus, all of our harvest treatments appeared to

478 continue to provide large trees for foraging. Therefore, we do not have evidence to

479 suggest that foraging trees are limiting in the Algonquin study area.

480 We expected that nest tree characteristics would be associated with variation in

481 nest survival and that favourable characteristics could then be incorporated into a

482 recommendation for new guidelines on wildlife tree characteristics. However, Brown

483 Creeper nest survival was not affected by nest tree characteristics or placement in the

484 landscape. Quiet vocalizations, small size and very inconspicuous nests may help to

485 protect Brown Creeper from nest predation in their highly specialized nesting sites as nest

486 success was relatively high in this study in comparison to that described for other

487 passerines nesting in the same landscape (Falk et al. 2011). Similar to our result, Brown

488 Creeper nest success in New Brunswick was not impacted by partial harvest, although in

489 that study the number of territories that produced at least 1 young was significantly

490 higher in the control stands (Poulin et al. 2010). The difference in methodology between

491 our studies may explain the difference in our results. 
While our sample size for any particular selection system was too small to

493 evaluate each method individually, average Brown creeper density was consistently

494 lower in each logged treatment than in the controls. While we are unable to make a strong

495 inference about which specific treatments are the least harmful to Brown Creeper

496 densities, we found fewer nests in stands affected by intensive group-selection than we

497 anticipated given that the uncut areas between gaps were not logged using this

498 experimental methodology. This method of silviculture also created the most amount of

499 fragmented forest because it contained more gaps. In addition, Brown Creeper nests were

500 closer on average, to forested wetlands in intensive group-selection stands than in other

501 treatment types (Geleynse 2012 M.Sc. thesis). These observations suggest that even

502 though some snags may have been retained in the upland hardwood matrices, there were

503 insufficient snags for breeding. Thus, this method appears to have the strongest negative

504 impacts on Brown Creeper.

505 As current wildlife tree provisions focusing on cavity dependent wildlife state that

506 the tree to be retained must be alive (OMNR 2010), lower density of Brown Creeper in

507 logged sites is, as indicated above, probably the result of inadequate provision of critical

508 nesting habitat features under these guidelines. Selection silviculture over the entire

509 landscape will not likely maintain optimal Brown Creeper nesting and foraging habitat.

510 Although lowland conifer forests adjacent to and often surrounding the upland stands

511 may provide nesting and foraging refuge areas for Brown Creeper following logging, our

512 findings of loss of Brown Creeper territories especially in the dominant land cover of the

513 upland forest is a significant concern on a landscape level because of the lower

514 productivity per hectare that this represents. Recommendations to keep large snags of 
515 preferred species in harvested areas are not compatible with current silvicultural practices

516 because they are in direct conflict with the Ontario's Occupational Health and Safety Act

517 (Ontario Ministry of Labour 2010). Revising the wildlife tree guidelines to retain a

518 portion of uncut area in the upland hardwood area that is roughly the size of a Brown

519 Creeper territory (10 ha) (Poulin et al. 2008, 10.4 ha) or larger that contain snags as well

520 as large living trees (especially yellow birch) may be more beneficial to Brown Creeper

521 than saving a particular number of live cavity trees (10) dispersed throughout the

522 cutblock. We suggest that this size of area be retained at a minimum because anything

523 less might be too small if the adjacent forest is unsuitable. However, this size may be

524 efficiently used by possibly more than one nesting Brown Creeper territory since the area

525 adjacent to the retained block could be used as supplemental foraging habitat. On a

526 landscape scale these uncut patches could make up a target percentage of the entire

527 prescribed area. It may be possible to maintain Brown Creeper densities by retaining

528 more (up to $50 \%$ ) upland hardwoods since the forested wetlands will already be retained.

529 These areas would also be beneficial to other old growth forest specialists.

\section{Acknowledgements}

531 We thank the many field assistants for their help in locating nests and collection

532 of vegetation data. We are extremely grateful to the reviewers for their comments and

533 input on this manuscript. We would like to thank the Algonquin Forestry Authority for

534 orchestrating the experimental logging. The project would not have been possible without

535 financial support from Trent University, Ontario Ministry of Natural Resources,

536 Algonquin Forestry Authority, and the Algonquin Wildlife Research Station. 


\section{References}

Adams, E.M., and Morrison, M.L. 1993. Effects of forest stand structure and composition on Red-breasted Nuthatches and Brown Creepers. J. Wildl. Manage. 57(3): 616629. doi: $10.2307 / 3809292$

Algonquin Forestry Authority. 2010. Algonquin Forestry Authority [online]. Avai lable from http://www.algonquinforestry.on.ca/index.htm [accessed on 20 April 2012] [accessed 20 April 2012].

Angelstam, P. K., Bütler, R., Lazdinis, M., Mikusinski, G., and Roberge, J.M. 2003. Habitat thresholds for focal species at multiple scales and forest biodiversity conservation-dead wood as an example. Ann. Zool. Fenn. 40: 473-482.

Buckland, S.T., Burnham, K.P., and Augustin, N.H. 1997. Model selection: An integral part of inference. Biometrics 53(2): 603-618.

Burnham, K.P., and D.R. Anderson. 1998. Model selection and inference: a practical information-theoretical approach. New York: Springer-Verlag.

Calenge, C. 2006. The package adehabitat for the R software: a tool for the analysis of space and habitat use by animals. Ecological Modelling, 197(3-4): 516-519. Available from: http://dx.doi.org/10.1016/j.ecolmodel.2006.03.017

Campbell, S.P., Witham, J.W., and Hunter, M.L. 2007. Long-term effects of groupselection timber harvesting on abundance of forest birds. Conserv. Biol. 21(5): 1218-1229. doi: 10.1111/j.1523-1739.2007.00768.x 
Dinsmore, S,J., White, G.C., and Knopf, F.L. 2002. Advanced techniques for modeling avian nest survival. Ecology 83(12): 3476-3488. Available from http://dx.doi.org/10.1890/0012-9658(2002)083[3476:ATFMAN]2.0.CO;2

ESRI (Environmental Systems Resource Institute). 2011. ArcMap 10. ESRI, Redlands, California.

Falk, K., Elliott, K. A., Burke, D., and Nol, E. 2010. Early seedling response to group selection harvesting in a northern hardwood forest. For. Chron. 86(1): 100-109. doi: $10.5558 / \mathrm{tfc} 86100-1$

Falk, K.J., Nol, E., and Burke, D.M. 2011. Weak effect of edges on avian nesting success in fragmented and forested landscapes in Ontario, Canada. Land. Ecol. 26: 239251. doi: 10.1007/s10980-010-9543-5

Flaspohler, D.J., Temple, S.A., and Rosenfield, R.N. 2001. Species-specific edge effects on nest success and breeding bird density in a forested landscape. Ecol. Appl. 11(1): 32-46. doi: $10.2307 / 3061053$

Franzreb, K.E. 1985. Foraging ecology of Brown Creepers in a mixed-coniferous forest. J. Field Ornithol 56(1): 9-16

Geleynse, Daniel. 2012. Brown Creeper (Certhia americana) Habitat Selection and Demography between Logged and Unlogged Forests of Algonquin Provincial Park, Canada. MSc. Thesis, Biology Department, Trent University, Peterborough, ON. 
Hartley, M.J., and Hunter, M.L. 1998. A meta $\square$ analysis of forest cover, edge effects, and artificial nest predation rates. Conserv. Biol. 12(2): 465-469. doi: 10.1111/j.15231739.1998.96373.x

Holloway, G.L., Caspersen, J.P., Vanderwel, M.C., and Naylor, B. 2007. Cavity tree occurrence in hardwood forests of central Ontario. Forest Ecology and Management 239(1-3): 191-199. Available from:

http://dx.doi.org/10.1016/j.foreco.2006.12.004http://www.sciencedirect.com/scien ce/help/doi.htm

Jones, J. 2001. Habitat selection studies in avian ecology: A critical review. Auk 118(2): 557-562. doi: http://dx.doi.org/10.1642/0004 8038(2001)118[0557:HSSIAE]2.0.CO;2

Leblanc, J.P., Burke, D.M., Nol, E. 2011. Ovenbird (Seiurus aurocapilla) demography and nest-site selection in response to single-tree selection silviculture in a Northern Hardwood Managed Forest Landscape. Ecoscience 18(1): 26-36.

Lindenmayer, D.B., Franklin, J.F., and Fischer, J. 2006. General management principles and a checklist of strategies to guide forest biodiversity conservation. Biol. Conserv. 131(2006): 433-45. doi:10.1016/j.biocon.2006.02.019

Mahon, C.L., Steventon, J.D., Martin, K. 2008. Cavity and bark nesting bird response to partial cutting in northern conifer forests. For. Ecol. and Manage. 256(12): 21452153. http://dx.doi.org/10.1016/j.foreco.2008.08.005 
Manly, B.J., McDonald, L.L., Thomas, D.L., McDonald, T.L., and Erickson, W.P. 2002. Resource selection by animals: Statistical design and analysis for field studies. Kluwer Academic Publishers.

Martin, N.D. 1960. An analysis of bird populations in relation to forest succession in Algonquin, Provincial Park, Ontario. Ecology 41(1): 126-140. Available from: http://dx.doi.org/10.2307/1931946

Medin, D.E., and Booth, G.D. 1989. Responses of birds and small mammals to singletree selection logging in Idaho. USDA Forest Service Intermountain Research Station Research Paper INT-408, Ogden, Utah, USA.

Moorman, C.E., and Guynn, D.C. Jr. 2001. Effects of group-selection opening size on breeding bird habitat use in a bottomland forest. Ecol. Appl. 11(6): 1680-1691. Available from: http://dx.doi.org/10.1890/10510761(2001)011[1680:EOGSOS]2.0.CO;2

Ontario Ministry of Labour. 2010. Ontario Health and Safety Act and Regulations. Thomson Carswell, Toronto, Ontario, Canada.

Ontario Ministry of Natural Resources. 2000. A silvicultural guide to managing southern Ontario's forests. Queen's Printer for Ontario, Toronto, ON.

Ontario Ministry of Natural Resources. 2004. Ontario tree marking guide, version 1.1. Queen's Printer for Ontario, Toronto, ON. 
Ontario Ministry of Natural Resources. November 2009. Forest information manual 2009. Forest Resources inventory Technical Specifications. Toronto: Queen’s Printer for Ontario. pp. 93

Ontario Ministry of Natural Resources. 2010. Forest management guide for conserving biodiversity at the stand and site scales. Toronto: Queen's Printer for Ontario. pp. 211

Orians, G.H., Pearson, N.E., 1979. On the theory of central place foraging. In: Horn, D.J., Mitchell, R.D., Stairs, G.R. (Eds.), Analysis of Ecological Systems. The Ohio State University Press, Columbus, pp. 154-177.

Poulin, J-F., D’Astous, E., Villard, M.A., Hejl, S.J., Newlon, K.R., Mcfadzen, M.E., Young, J.S., Ghalambor, C.K. 2013 Brown Creeper (Certhia americana), The Birds of North America Online (A. Poole, Ed.). Ithaca: Cornell Lab of Ornithology. Retrieved from Birds of North America Online: http://bna.birds.cornell.edu/bna/species/669

Poulin, J-F., Villard, M.A., Edman, M., Goulet, P.J., and Eriksson, A.M. 2008. Thresholds in nesting habitat requirements of an old forest specialist, the Brown Creeper (Certhia americana), as conservation targets. Biol. Conserv. 141(4): 1129-1137. Available from: http://dx.doi.org/10.1016/j.biocon.2008.02.012 Poulin, J-F., and Villard M.A., and Hache, S. 2010. Short-term demographic response of an old forest specialist to experimental selection harvesting. Ecoscience 17(1): 2027 
Poulin, J-F., and Villard M.A. 2011. Edge effect and matrix influence on the nest survival of an old forest specialist, the Brown Creeper (Certhia americana). Land. Ecol. 26(2011): 911-922. doi: 10.1007/s10980-011-9615-1

Purcell, K.L., Thompson, C.M., Drynan, D.A. 2012. Response of Brown Creepers to elevation and forest edges in the Southern Sierra Nevada, California. Condor 114(1): 185-196. Available from: http://dx.doi.org/10.1525/cond.2012.100181

Quinn, N.W.S. 2004. The presettlement hardwood forests and wildlife of Algonquin Provincial Park: a synthesis of historic evidence and recent research. For. Chron. 80(6): 705-717. doi: $10.5558 / \mathrm{tfc} 80705-6$

R development core team. 2011. R: A language and environment for statistical computing. R Foundation for Statistical Computing, Vienna, Austria. Available from: http://www.r-project.org/

Rotella, J. 2011. Nest survival models, Chap 17. In: Cooch E, White G (eds) Program Mark, a gentle introduction, $9^{\text {th }}$ edn. Available from: www.phidot.org/software/mark/docs/book/[accessed 16 January 2012]

SPSS software. 2010. SPSS Base 20.0. SPSS Inc., Chicago, IL.

Tozer, D.C., Burke, D.M., Nol, E., and Elliot, K.A. 2010. Short-term effects of groupselection harvesting on breeding birds in a northern hardwood forest. For. Ecol. Manage. 259(8): 1522-1529. Available from: http://dx.doi.org/10.1016/j.foreco.2010.01.028 
Vanderwel, M.C., Malcolm, J.R., and Mills, S.C. 2007. A meta-analysis of bird responses to uniform partial harvesting across North America. Conserv. Biol. 21(5): 12301240.

Vitz, A., and Rodewald, A. 2006. Can regenerating clearcuts benefit mature-forest songbirds? an examination of post-breeding ecology. Biol. Conserv. 127(4): 477486. Available from: http://dx.doi.org/10.1016/j.biocon.2005.09.011

White, G.C., and Burnham, K.P. 1999. Program MARK: survival estimation from populations of marked animals. Bird Study 46(Suppl 001): 120-139. doi:10.1080/00063659909477239

White, G.C., Burnham, K.P., and Anderson, D.R. 2001. Advanced features of Program Mark. Int. Wildl. Manage. Congr. 7.5: 368-377

Wiggins, D.A. 2005. Brown Creeper (Certhia americana): a technical conservation assessment. USDA Forest Service, Rocky Mountain Region. Available from http://www.fs.fed.us/r2/projects/scp/assessments/browncreeper.pdf [accessed 24 January 2012]

Wintle, B.A., Bekessy, S.A., Venier, L.A., Pearce, J.L., and Chisholm, R.A. 2005. Utility of dynamic-landscape metapopulation modeling for sustainable forest management. Conserv. Biol. 19(6): 1930-1943. doi: 10.1111/j.15231739.2005.00276.x 
Table 1. Model selection results with 25 models examining age/date/treatment effects on Daily Survival Rate (DSR) for Brown Creepers in Algonquin Provincial Park, Ontario. The variables examined were Date (Julian date), treatment (Control vs. Logged), nest age, and year (2010-2011). A superscript (e.g., Nest age ${ }^{2}$ ) indicates a quadratic effect. The model Nest age ${ }^{2}+$ Date + Year had the lowest AICc of 195.997.

\begin{tabular}{|c|c|c|}
\hline Model & Delta AICc & $\begin{array}{l}\text { Model } \\
\text { Likelihood }\end{array}$ \\
\hline Nest $\mathrm{Age}^{2}+$ Year + Date & 0 & 1 \\
\hline Date + Year & 0.038 & 0.9812 \\
\hline Date & 0.1397 & 0.9325 \\
\hline Nest Age $^{2}+$ Date & 0.755 & 0.6856 \\
\hline Date + Year + Nest Age & 1.0792 & 0.5829 \\
\hline Date + Nest Age & 1.3434 & 0.5109 \\
\hline Date + Treatment & 1.421 & 0.4914 \\
\hline Date + Treatment + Year & 1.44 & 0.4867 \\
\hline Nest $\mathrm{Age}^{2}+$ Year + Date + Treatment & 1.7367 & 0.4196 \\
\hline Year + Nest Age & 2.1369 & 0.3435 \\
\hline Nest Age & 2.3218 & 0.3132 \\
\hline Nest $\mathrm{Age}^{2}+$ Date + Treatment & 2.3299 & 0.3119 \\
\hline Date + Treatment & 2.7419 & 0.2539 \\
\hline Date + Treatment + Nest Age & 2.8703 & 0.2381 \\
\hline Year & 3.4612 & 0.1772 \\
\hline Treatment + Year + Nest Age & 3.5421 & 0.1701 \\
\hline Treatment + Nest Age & 3.5815 & 0.1668 \\
\hline Nest Age $^{2}+$ Year & 3.8206 & 0.1481 \\
\hline Nest $\mathrm{Age}^{2}$ & 4.0348 & 0.133 \\
\hline Constant & 4.2186 & 0.1213 \\
\hline Treatment + Year & 5.3763 & 0.068 \\
\hline Nest $\mathrm{Age}^{2}+$ Year + Treatment & 5.432 & 0.0661 \\
\hline Nest Age $^{2}+$ Treatment & 5.4847 & 0.0644 \\
\hline Treatment & 6.0602 & 0.0483 \\
\hline
\end{tabular}


Table 2. Model selection results with 10 variables evaluating the importance of nest tree characteristics (\% bark cover, tree species, diameter at breast height (DBH), health (snag vs. alive), placement in the landscape (distance to edge, distance to forested wetland, basal area, canopy cover), and nest characteristics (height and concealment) on DSR of Brown Creeper nests (2010-2011, Algonquin Provincial Park, Ontario). All models contain top age/date/treatment model (Nest age ${ }^{2}+$ Year + Date), which also had the lowest AICc of 195.997.

Model

Model Delta AICc

Nest $\mathrm{Age}^{2}+$ Year + Date Likelihood

Health 0.6645

0.7173

DBH

1.2602

0.5325

Canopy cover

1.4824

0.4766

Nest height

1.6753

0.4327

Basal area

1.7181

0.4236

Concealment

1.8152

0.4035

Bark cover

1.8699

0.3926

Dist. to forested wetland

1.9705

0.3733

Tree species

1.9742

0.3727

Dist. to edge

2.0078

0.3664

Constant

4.2186

0.1213 
Table 3. Site (obtained from randomly selected trees) and nest tree characteristics for Brown Creeper in each silvicultural treatment in Algonquin Provincial Park, Ontario.

Habitat Perimeter

\section{Site}

Basal area $\left(\mathrm{m}^{2} / \mathrm{ha}\right)$

2 factor prism

$\%$ snag

$\%$ declining trees

$\%$ live trees

$\%$ upland hardwood forest

$\%$ mixed forest

\section{Nest tree}

Basal area $\left(\mathrm{m}^{2} / \mathrm{ha}\right)$

2 factor prism

$\%$ in forested wetland

$\%$ in upland hardwood forest

$\%$ in snag

$\%$ in conifer tree species

\section{Contro}

$20.6 \pm 1.1 \quad 16.2 \pm 2.5$

$12(21 / 179) \quad 2(2 / 105)$

$36(64 / 179) \quad 40(42 / 105)$

$52(94 / 179) \quad 58(61 / 105)$

$72 \pm 14$

$23 \pm 15$

$23 \pm 10$

Silvicultural Treatment

\section{Intensive group}

Typical group selection

$14.4 \pm 1.3$

$2(3 / 162)$

$43(69 / 162)$

$55(90 / 162)$

$65 \pm 15$

$35 \pm 14$

$6 \pm 2$

$2(1 / 41)$

$29(12 / 41)$

$69(28 / 41)$

$94 \pm 2$
$26 \pm 11$

Recent single tree selection

$16.4 \pm 1.2$

$5(4 / 86)$

$42(36 / 86)$

$53(46 / 86)$

$74 \pm 14$ 
Table 4. Least-squared means from general linear models testing whether DBH, height and moss cover varied between treatments and between those used for foraging by Brown Creepers and those randomly selected. Letters indicate cell that has a parameter estimate is significantly different than others.

Silvicultural treatment

\begin{tabular}{|c|c|c|c|c|c|c|}
\hline Character & $\begin{array}{l}\text { Forage or } \\
\text { random }\end{array}$ & Control & $\begin{array}{l}\text { Intensive } \\
\text { Group- } \\
\text { selection }\end{array}$ & $\begin{array}{l}\text { Typical } \\
\text { group- } \\
\text { selection }\end{array}$ & $\begin{array}{l}\text { Old single tree } \\
\text { selection }\end{array}$ & $\begin{array}{l}\text { Recent Single } \\
\text { Tree Selection }\end{array}$ \\
\hline \multirow[t]{2}{*}{ DBH (cm) } & Forage & $40.21 .70^{\mathrm{a}}$ & 30.92 .27 & 33.41 .91 & 36.53 .19 & 32.32 .03 \\
\hline & Random & 32.81 .16 & 29.41 .49 & 29.61 .20 & 31.23 .23 & 30.21 .53 \\
\hline \multirow[t]{2}{*}{ Height (m) } & Forage & 23.20 .6 & 21.00 .8 & 22.40 .7 & 24.61 .1 & 21.20 .7 \\
\hline & Random & 17.20 .4 & 17.90 .5 & 16.70 .4 & 18.41 .1 & 19.30 .5 \\
\hline \multirow{2}{*}{$\begin{array}{l}\text { Moss }(\% \\
\text { cover })\end{array}$} & Forage & 39.43 .2 & 37.54 .12 & 49.53 .6 & 31.55 .8 & 33.64 .2 \\
\hline & Random & 35.42 .12 & 35.12 .7 & 36.22 .19 & 33.95 .89 & 39.22 .8 \\
\hline
\end{tabular}


Table 5. Brown Creeper nest parameters (Julian date of first egg, clutch size, length of nestling period, and Julian fledge date) mean \pm SE (n) estimates in $2010(n=24)$ and 2011 (37) for control and logged silvicultural treatments.

$\underline{2010}$

Control

\section{$\underline{\text { Logged }}$}

$P$

Control

2011

\section{Logged}

$P$

First egg date $\quad$ May 5 $\pm 1.4(11) \quad$ May 5 $\pm 1.2(13) \quad 0.89 \quad$ May $13 \pm 1.4(12) \quad$ May $13 \pm 0.7(25) \quad 0.83$

$\begin{array}{lllllll}\text { Clutch size } & 5.7 \pm 0.4(6) & 5.9 \pm 0.1(7) & 0.66 & 6.1 \pm 0.2(9) & 6.16 .1 \pm 0.1(18) & 0.81\end{array}$

$\begin{array}{llllll}\text { Nestling stage } & 16 \pm 0(5) & 15.3 \pm 0.7(3) & 0.22 & 16 \pm 0.4(4) & 16.1 \pm 0.1(14)\end{array}$

Fledge date $\quad$ Jun $10 \pm 1.8(8) \quad$ Jun $10 \pm 1.3(11) \quad 1.00 \quad$ Jun $19 \pm 1.1(10) \quad$ Jun18 \pm 0.7 (21) $\quad 0.50$ 
Figure 1. Breeding density (pairs/ha) of Brown Creeper in each silvicultural treatment and a category with all logged stands. The top of the box represents the $75^{\text {th }}$ percentile, the centerline in the box represents the $50^{\text {th }}$ percentile and the bottom of the box represents the $25^{\text {th }}$ percentile. The whiskers extending from the top and bottom of the box represent the highest and lowest values.

Figure 2.a Manly Selectivity ratio \pm CI for Brown Creeper nest tree species in control and logged sites. The dot shows the mean selectivity of each tree species used as nesting substrate. The tree species is considered preferred when the mean is above 1 and the CI does not include 1 . The tree species is considered proportionately under-utilized if the mean is below one and the CI is located from $0-1$. If the CI includes 1 the tree species is selected proportionately to its availability. Nest sample size (n) is included.

Figure 2.b Manly Selectivity ratio \pm CI for Brown Creeper foraging tree species in control and logged sites. 
Fig. 1

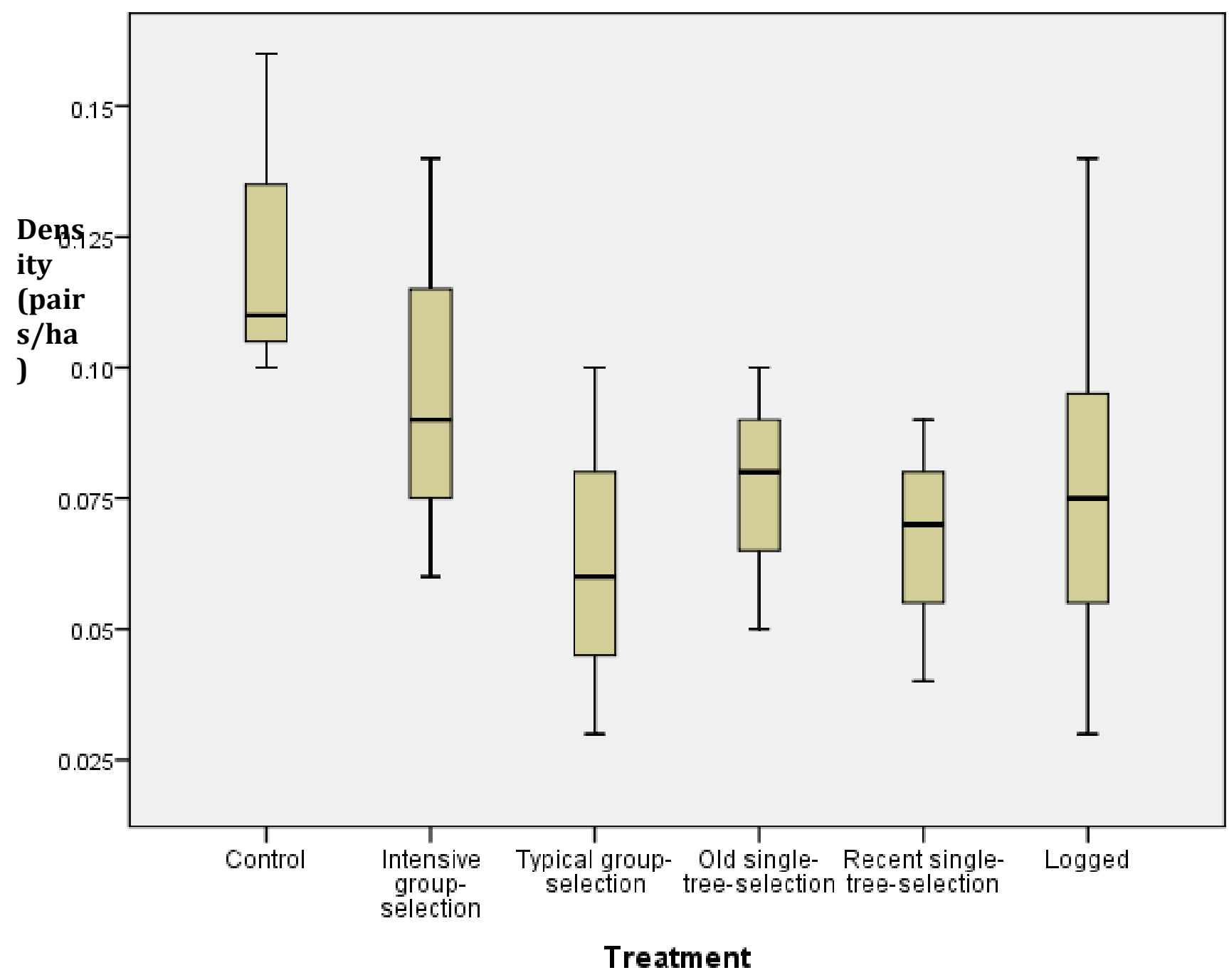


Fig. 2.b

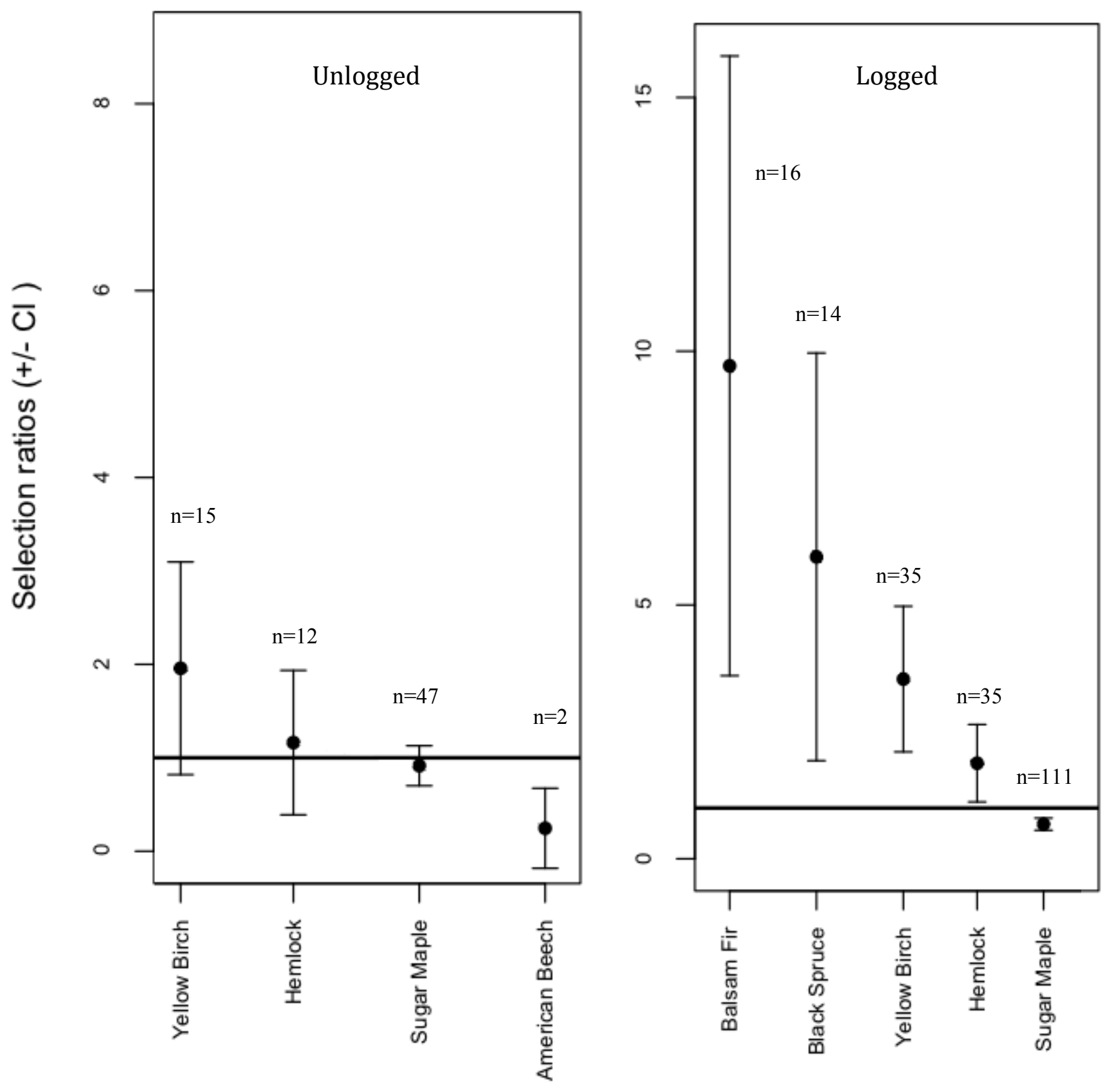


Fig. 2.a

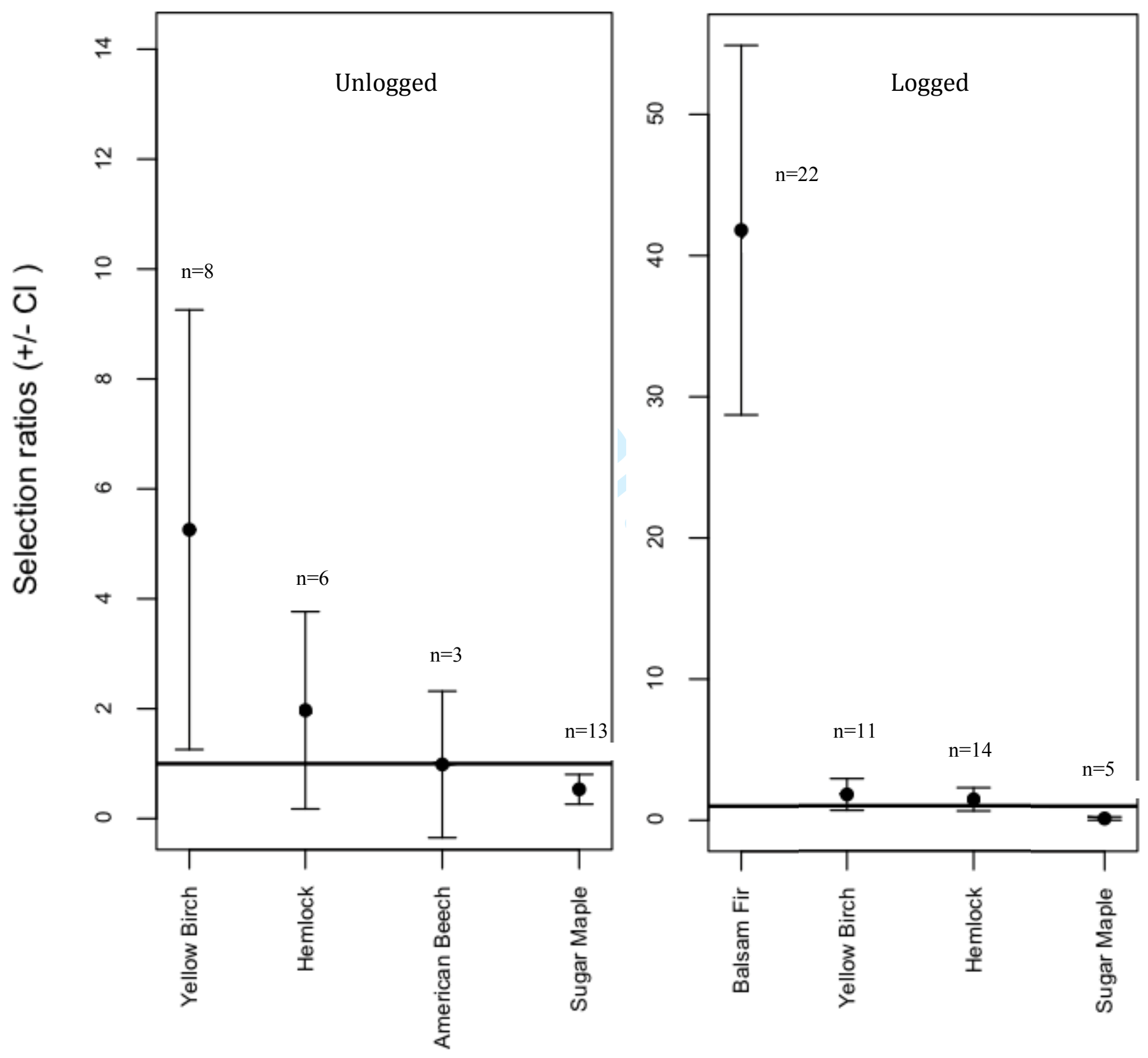

